\title{
パルセイティングストレスクリープ特性に関する研究 (II)*
}

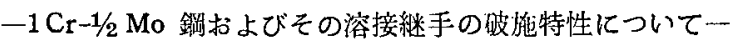

\author{
渡 辺 正 紀** 小川 清 六***
}

\section{A Study of Pulsating Stress Creep Characteristics (II)*}

-Rupture properties of $1 \mathrm{Cr}-1 / 2 \mathrm{Mo}$ steel and their welds-

by Masaki Watanabe** and Seiroku Ogawa***

\begin{abstract}
The previous report $(1)$ has shown the rupture characteristics of mild steel at $450^{\circ} \mathrm{C}$ under the stress conditions of a relatively small pulsating stress being superimposed on the static tensile stress which is sufficient to produce a creep rupture.

The work described in this paper is concerned with the rupture properties of $1 \mathrm{Cr}-1 / 2 \mathrm{Mo}$ steel and their welds at $550^{\circ} \mathrm{C}$ under the similar conditions of stress to those mentioned above.

The amplitude-to-mean stress ratios $\mathrm{A}\left(\sigma_{a} / \sigma_{m}\right)$ selected for this experiment were 0 (static), 10,20 and $40 \%$.

The results ogtained are summarized as follows:

1. The mean stress versus time for rupture diagram in $\log$-log plots showed that the rupture life decreased with an increasing stress amplitude ratio $\mathrm{A}$ and the static stress rupture had the longest life.

2. The stress-rupture diagram plotted on the basis of maximum (crest) stress in the stress cycle in view of fatigue behavior showed that the rupture life increased with an increasing stress ratio $\mathrm{A}$ and the static stress rupture had the shortest life, being incompatible with fatigue behavior.

3. Rupture characteristics under pulsating stress were investigated from creep behavior by the same method of analysis as reported in previous paper(1). The superposition of alternating stress resulted in a decline of rupture strength, supposedly due to the dynamic effect, for the base metal but in no decline in the welded joint except for the shot-life tests.

4. Ductilities of test specimen, determined by true strain at the fractured section, did not show remarkable difference in static and pulsating stress rupture between base metal and welded joint.

Welded joint showed lower ductilities than base metal.

5. There was no remarkable difference in situation of fracture in welded specimens between static and pulsating stress rupture. Most of their fractures occured at the base metal adjoining the heat affected zone in short-life test and approached the deposit metal with an increase of rupture life.
\end{abstract}

\section{1. 緒言}

高温下でクリープ挙動が顕著にあらわれるような引張 り応力に，比較的小さい繰り这し応力が脈動的飞重胃さ れるいわゆるパルセイティング ストレス下の材料の変 形ならびに破断に関する一連の研㒭を行なうに当たっ て，まずその基礎研究として，前報〉で軟鎙に対して $450^{\circ} \mathrm{C}$ で行なった実験の結果を報告した。それによるよ パルセィティング ストレスの平均応力 $\sigma_{m}$ に対する伈 力振巾 $\sigma_{a}$ の比 $\sigma_{a} / \sigma_{m}$ であらわされる応力比か $30 \%$ \%い

\footnotetext{
* 原稿受付 昭和43年 1 月22日（39年度浴接学会春季大会に一発表）

**正 員 大陵大学工学部 Member, Faculty of Engineering Osaka University

*** 正員 大阪府立大学工学部 Member, University of
}

どといったように，片振り疲れに比べて比較的小さい場 合，その破断がパルセィティング ストレスによる静的 なクリープ損倣の䇣積によって起てると仮定して求めた 等価静応力 $\sigma_{e q}$ をパルセイティング ストレス下の材料 の破断溞度とすると, 静クリープ破断竹度にほぼ等し くなり，雨者の応力一破断時間線图は比較的よく一致す るという結果が得られた。このことから, 軟柃では, $450^{\circ} \mathrm{C}$ といった高温でクリープ現象が影著にあらわれる 条件下では, 静応力に応力比 $\sigma_{a} / \sigma_{m}$ が30\%ていどのパ ルセイティング ストレスが重䏣されても，その破断 挙動を支配するものは主としてクリープ挙動であると若 えられるのであって，繰り这し応力による疲れ挙動ある いは動応力の影響，た之えば応力繰り这しに伴なう過渡 的な歪あるいは損鹪の罢穔といったようないわゆる静的 
クリープ損傷以外の損鹪の影響はほとんど認められない ことが明らかにせられた。

本報では高温用材料として広く用いられている $1 \mathrm{Cr}$ $1 / 2 \mathrm{Mo}$ 鋼极よびその溶接継手について, $550^{\circ} \mathrm{C}$ に扔い て同様な実験を行ない，軟鋼に比べて静クリープ抵抗 が高いとすくされている Cr-Mo 鋼が, パルセイティン グ ストレス下でどのような破断特性を示すかをみると とあに，軟龬と比較して，その破断特性に異なるとてろ があるかどうかを検討した．また溶接継手に対する実験 加ら，溶接継手の破断特性を求め，母材のそれ之比較す るとともに，パルセィティング ストレスが溶接部に刘 してどのような影響を及ぼすか，すなわち溶接継手のパ ルセィティング ストレス下の破断が，とくにその破断 寿命あるいは破断位置からみて，静クリープ破断と異な るところがあるかどうかを検討した，乙の場合溶接前後 の熱処理によって溶接部の組織か改善され母材のそれに 近くなると，パルセイティング ストレスに対する溶接 の影響をみるうえにあまり効果がないと考えられるの で，第一着手としてとくに溶接のままの試験片だけにつ いて実験を行なっだ。

\section{2. 実 験 方 法}

\section{1 供試材}

供試材は Table 1 亿示すような組成の $1 \mathrm{Cr}-1 / 2 \mathrm{Mo}$ 鋼で, 本実験用として $1 \mathrm{~m} \times 10 \mathrm{~cm} \times 13 \mathrm{~mm}$ の寸法にと くに圧延されたあのをあらかじめ $930^{\circ} \mathrm{C} 45$ 分加熱後 $150^{\circ} \mathrm{C} / \mathrm{h}$ の玲却速度で炉冷の熱処理を施てしたのち使 用した。

Table 1 Chemical composition of Cr-Mo steel

\begin{tabular}{c|c|c|c|c|c|c|c}
\hline \multicolumn{10}{c}{ Elements \% } \\
\hline $\mathrm{C}$ & $\mathrm{Si}$ & $\mathrm{Mn}$ & $\mathrm{Cr}$ & $\mathrm{Mo}$ & $\mathrm{Cu}$ & $\mathrm{P}$ & $\mathrm{S}$ \\
\hline 0.12 & 0.29 & 0.58 & 0.90 & 0.47 & 0.12 & 0.011 & 0.020 \\
\hline
\end{tabular}

\section{2 母材試験片}

母材試験片は，静クリープ，パルセィティング スト レスクリープ雨試験とも，Fig. 1 亿示すような形状 のクリープ試験片を板の圧延方向に採取した。

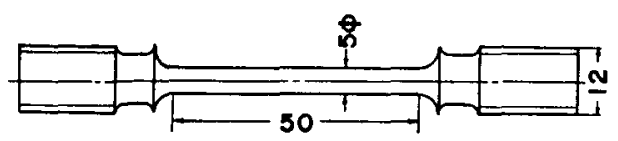

Fig. 1 Test specimen

\section{3 溶接継手試験片}

溶接継手試験片は，母材を圧延方向に，約 $70 \mathrm{~mm}$, そ

\footnotetext{
*溶接後の熟処理を行なったものについては別に報告する予定である.
}

れと直角方向に約 $100 \mathrm{~mm}$ の大きさに切り出したあの を 2 枚实き合わせ溶接した溶接継手から採取した。溶接 継手の形状ならびに試験片の採取位置は Fig. 2 に示す とおりである.
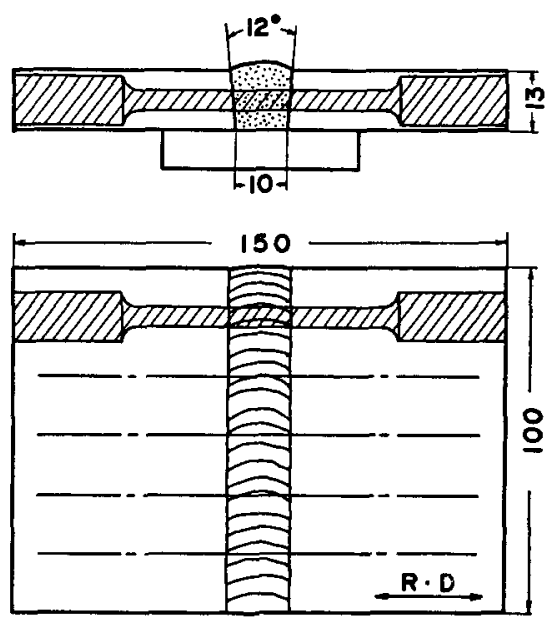

Fig. 2 Joint design and location of test specimen

溶接は Table 2 に示すような組成の $1 \mathrm{Cr}-1 / 2 \mathrm{Mo}$ 鐥 用被覆アーク溶接棒を用い手動アーク溶接で行なった。 溶接条件はつぎのとおりである.

Table 2 Chemical composition of welding rod used

\begin{tabular}{c|c|c|c|c|c|c}
\hline \hline $\mathrm{C}$ & $\mathrm{Si}$ & $\mathrm{Mn}$ & $\mathrm{Cr}$ & $\mathrm{Mo}$ & $\mathrm{P}$ & $\mathrm{S}$ \\
\hline 0.09 & 0.22 & 0.40 & 1.05 & 0.50 & 0.015 & 0.005 \\
\hline
\end{tabular}

層数； 6 層，溶接電流；㵊 5 層 $180 \mathrm{Amp}$

なお溶接継手試験片の形状寸法は母材試験片之まった く同様であるが，試験片平行部中心汇溶接部がくるよう に，また平行部における母材部と，熱影響部を含めた溶 接部の寸法比率がほぼ：1 亿なるようにしている.

\section{4 実験方法}

$1 \mathrm{Cr}-1 / 2 \mathrm{Mo}$ 鋼の最高使用温度は一般に $500^{\circ} \mathrm{C}$ ぐらい までとされているが, 本実験では, クリープ現象が顕著 にあらわれて，比較的短時間で皮断が起こるように，实 験温度を $550^{\circ} \mathrm{C}$ とした，母材ならびに溶接継手につい て, 静クリープ破断試験およびパルせィティングスト レスクリープ破断試験を行ない，各応力に対する破断 時間を求めるとともに途中のクリープ電量す測定した。

パルセィティング ストレス クリープ試験の場合は、 繰り返し応力の平均応力 $\sigma_{m}$ 亿対する応力振巾 $\sigma_{a}$ の比 
$\sigma_{a} / \sigma_{m}$ であらわされる応力比 $\mathrm{A}$ が10, 20,40\%の3 種 類について実験を行なった，応力繰り返し速度は軟鋼の 実験之同様 $380 \mathrm{r} \cdot \mathrm{p} \cdot \mathrm{m}$ である.

使用試験機は筆者らが試怍したパルせィティング ス トレスクリープ試験機である.

\section{3 、実験結果ならひに考察}

前報の軟鋼に対する実験と同様な钼点にたって本䒠験 結果の検討ならびに考察を試みる。

\section{1 母材の破断特性について}

3.1 .1 繰り返し现力の平均応力 $\sigma_{m}$ による耀りり 一プ破断特性との比較

パルセィティング ストレス下の材料の破断に扔い て，脈動的な繰り返し応力が材料の破断寿命にどのよう な影響を及ぼすがクリープ挙動の見地から検討し， 静クリープ破断特性之比較するに当たって問題となるの は，比較基準応力として，パルセィティング ストレス のどの值をとるかということである，すなわち，前報で あのべたように，静クリープに拈ける破断寿命は応力の 指数関数としてあらわされるから，本駼験のように，正 弦形波状のパルセィティング ストレスをうける材料で は，その平均応力 $\sigma_{m}$ を境として，それ以上の応力によ るクリープ挙動あるいはクリープ損賃は，それ以下の応 力による場合よりあ，指数関数的化加速されるから，パ ルセイティング ストレス下の静的クリープ挙動を代表 するは応力パルセィティング ストレスの平均応力 $\sigma_{m}$ とはならない.したがって静クリープ破断特性と比較す る場合，比較基準応力として平均応力 $\sigma_{m}$ をとること にはあまり甞味がないわけであるが，ある応力を基準と して, 応力振巾 $\sigma_{a}$ が零の静クリープに対して, 応力振 巾 $\sigma_{a}$ を順次大きくしていったときの破断寿命がどのよう に变わるかを現象論的に考察するのに便利である.

とのような観点から，軟銅の笑験の場合之同様パルセ イティング ストレスによって破断したものについては 平均応力 $\sigma_{m}$ 一破断時間の関係两対数值を之って求 め, その破断特性を静クリープのそれと比較したのが

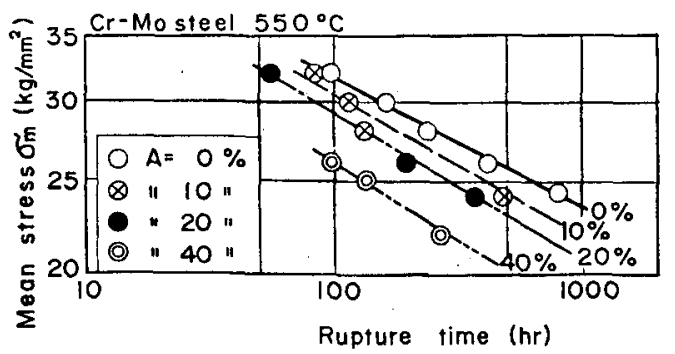

Fig. 3 Mean stress versus time to rupture diagram

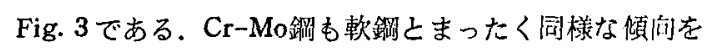
示し, 静クリープの応力一破断時閒線図之同様, パル セィティング ストレス下のそれむ，応力比 Aをパラメ 一タとしておのおの一本の直線であらわされ，各直線は いづれも静クリープの直線とほぼ平行となるようである が，応力比 $\mathrm{A}$ のきいるのほど静クリープに比べて急激

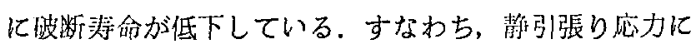
繰り这し応力を脈動的に重踖させたときの破断清命を繰 り这し応力の大きさ之の関係においてみてみると，繰り 返し応力の平均応力 $\sigma_{m}$ 一定で静クリープさせた之きの 破断寿命があっとも大きく，応力振巾が大きい屯のほど 破断寿命が著しく低下することがわかる.

3.1 .2 繰り返し五力の最大応力 $\sigma_{\max }$ に上る静ク リープ破断寿价との比較.

Fig. 4 は疲れ挙㗢の観点加ら, 繰り返し応力の最大心 力 $\sigma_{\max }$ と破断時間の関係莡阔刘数值をとって図示した

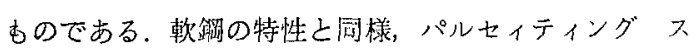
トレス下の破断浔命はいずれむ最大応力 $\sigma_{\max }$ で将クリ 一プさせたときよりも長くなり，しかる仙力比Aが大き いものほぎ破断表命が大きくなっている，てれはクリー

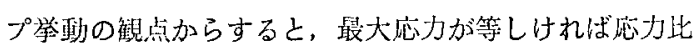
の大きいものほど平岣応力も小さくなるから，最大応力

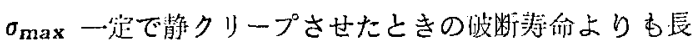
くなるのは当然のことであるが，疲れ挙動の見地からす れば，応力振巾の大きいものほど做断责命が長くなると いう矛盾した結果となっている。

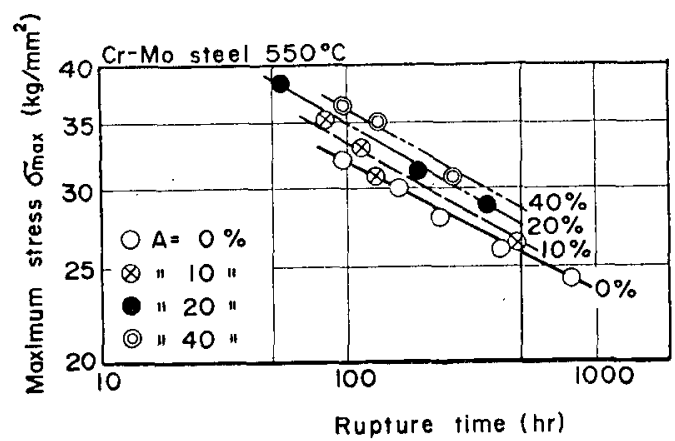

Fig. 4 Maximum stress versus time to rupture diagram

3.1 .3 クリープ挙動の見地からした静クリープ被 断との比較.

以上のような結果からすれば， $550^{\circ} \mathrm{C}$ の Cr-Mo 銤

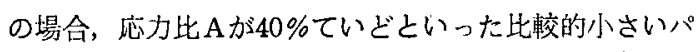
ルセィティング ストレス下の破断位しては，クリー プ挙動が文配的なようである。したがってクリープ挙動 
の見地からその破断特性を検討し, 静クリープ破断特性 と比較してみる.

前報でのべたようにパルセィティング ストレス下の 破断は繰り返し応力による静的クリープ損傷の累積によ って起こると仮定し，ての静们クリープ挙動を代表する 応力すなわちパルセィティング ストレス下の披断の静 クリープ破断化対する等㑑静応力 $\sigma_{e q}$ を求如，乙の等洒 静応力 $\sigma_{e q}$ 之破断時間の閐係吕ら静クリープ破断特性之 比較したのが Fig. 5 である. パルセィティング ス トレスによって破断したすのはいずれ屯破断時間が短い ところでは静クリープ破断寿命とそれほど変わらない が，破断時間が長い李のでは明らかに静クリープよりあ 破断寿命が低下している．しかす両者の破断専命の差は 長時間㽠断のものほど大きくなる傾问を示している.

てのように等佂静応力 $\sigma \mathrm{e}_{\mathrm{q}}$ で静クリープ佊断前度之比 較して破断寿命の低下が認められるということは，パル セィティング ストレス下の根断が単に繰り返し応力に よる単なる静附クリープ損賃の累樍だけでなく、“疲れ 举動”あるいは応力変動化伴なう“過渡的なクリープ举 動”などのいわゆるパルセィティング ストレスによる

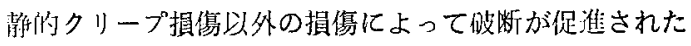
あのと考えられるのであって，前報でのべた $450^{\circ} \mathrm{C} の$ 吹鋼の場合には認められなかった現象りである。

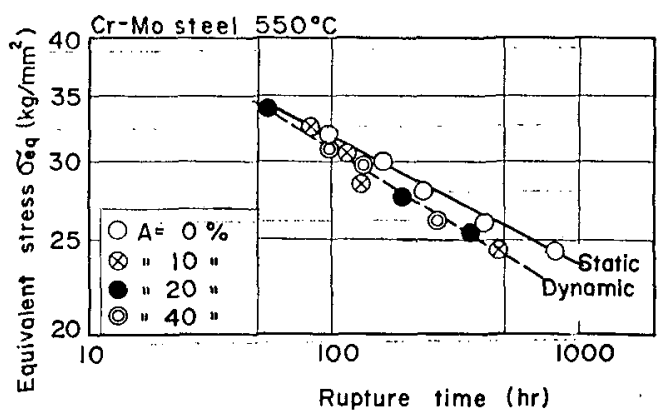

Fig. 5 Equivalent static stress versus time to rupture diagram

3.1 .4 静動雨クリープの破断にいたるまでの变坭 量ならびに材料の处性.

前節までは破断強さからパルセイティング ストレス 下の破断特性を静りリープのそれと此較したものである が，破断後の試験片の破断部真歪から破断にいたるまで の材料の伸びあるいは延性度を静・動耐クリープ佊断で 比較してみる之Fig. 6 のようになる。図は皮断時間之 畔断部点歪の関係を示したあのであるが，まず静クリー プ佊䉼についてみてみると，図中の点線で示した軟鋼に

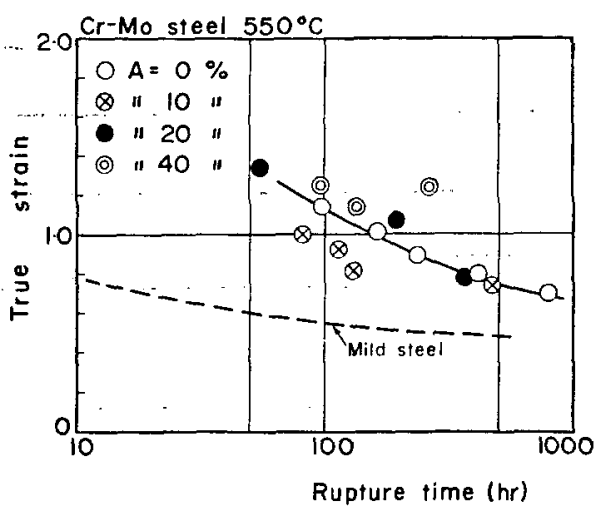

Fig. 6 Relation between rupture time and strain at fractured part

此ベて歪量はすべてかなり高くなっているが，破断時間 に対する破断部歪の低下の傾问は軟銓之同様であって， 長時間碳断のものほど䂭断部真歪は小さくなり，破断時 の局部收縮㽬が小さくなるととを示している.

これに刘してパルセィティング ストレスにより破断

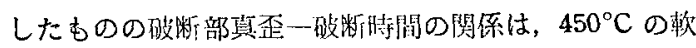
鋼の場合ほとんど静クリープ佊断と等しくなっだのに 比べると， $550^{\circ} \mathrm{C}$ の Cr-Mo 鋼ではそのバラッキはかな り大きい。しかし破断時間が唇いものはど歪が低下する 傾问は静クリープの場合上同様である。 また応力比 Aの 小さいむのでは静クリープの破断歪よりも小さくなる傾

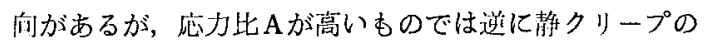
それよりあ大きくなる傾问がみられる。

しかし破断部真歪からみたパルセィティング ストレ ス クリープならびに静クリープの雨诐断挙㗢の差は, Fig. 5 でみられるような等洒静応力 $\sigma_{e q}$ であらわした パルセィティング ストレス下の狠断䖵度と静クリープ 破断強度の差のように明確ではない。乙れは両破断形式 に巨視湖な相違があらわれるほどパルセィティング ス トレスの影響が大きくないととを示しているものと思 われる。

\section{2 溶接継手の破断特性}

前項には母材の破断特性についてのべたが，溶接のま まの溶接継手の破断特性を母材の埸合之同梯な観点にた って検討した結果についてのべる.

3.2 .1 繰り返し応力の平均応力 $\sigma_{m}$ による静りリ 一プ破断特性との比較.

Fig. 7 は母材の場合之同様, パルセィティングス卜 レス下゙の㽠断時間と伈力の関係を, 絽り返し応力の平均 応力 $\sigma_{m}$ をとって雨対数目盛に図示し, 静クリープ破断 における応力一般䉼㭙聞線図と此較したものである。 


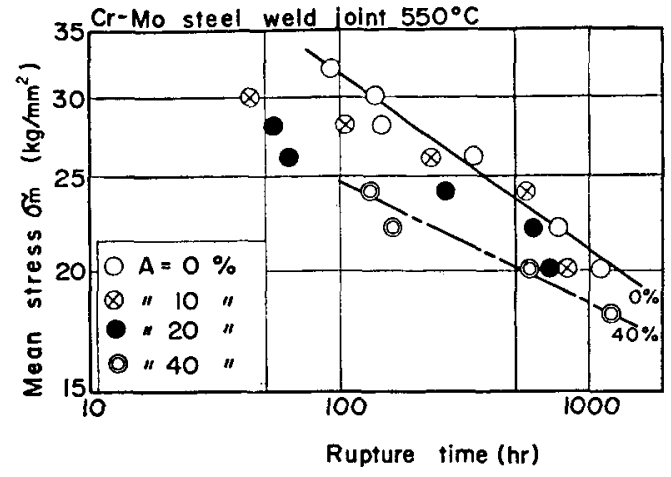

Fig. 7 Mean stress versus time to rupture diagram

溶接継手の場合には母材に比べると溶接に伴なう試験 片の不均一性からいずれも実験点自体のバラッキが大き いのであるが，パルセィティング ストレス下の破断寿 佮はいずれるその平均応力 $\sigma_{m}$ による静クリープ破断邦 命よりも短くなり，応力比Aの大きいあのほどその低下 度は著しいという現象は軟鋼および前述の $\mathrm{Cr}-\mathrm{Mo}$ 鋼母 材の婸合と同様である．ただ少し異なるところは，軟鋼 および Cr-Mo 鋼母材では応力比 Aが等しいものは破断 寿价の長短にかかわらず静クリープに対する低下率はほ とんぞ一定かあるいは差があってもきわめてわずかであ ったのに比べると，溶接継手の場合には応力の高い短時 間破断のむのは長㭙間破断のものに比べて破断寿命の低 下が著しいということである。したがってパルセィティ ング ストレス下の破断寿命はいずれも応力が小さくな るほど静クリープ破断寿命に近ずく傾向を示している。

3.2 .2 繰り返し応力の最大応力 $\sigma_{\max }$ による静ク リープ破断寿命との比較.

これを疲れの観点から繰り返し応力の最大応力 $\sigma_{\max }$ と破断時間の関係を雨対数值をとって図示すると Fig. 8

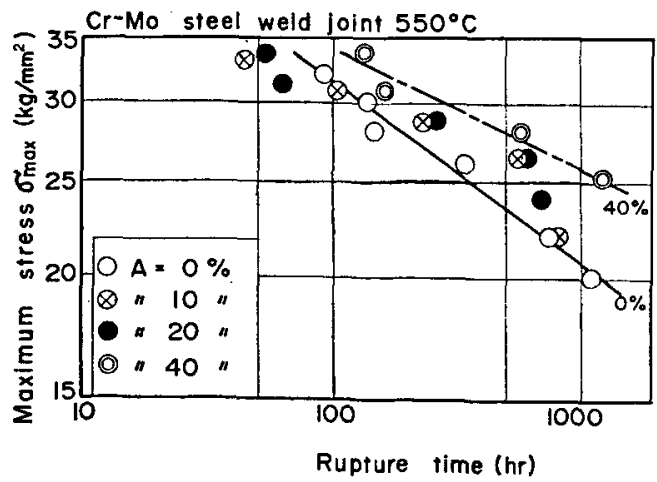

Fig. 8 Maximum stress versus time to rupture diagram
のようになる．100 時間以下の短時間側をのぞけば母材 の場合亡同様いずれも静クリープ破断寿命よりも長く， また応力比 Aが大きいものほど破断時間が唇くなってい る、したがって溶接継手の場合屯軟鋼あるいは $\mathrm{Cr}-\mathrm{Mo}$ 銻母材と同様パルセィティング ストレス下の佊䉼に対 してはクリープ笔動が支配的であると考えられる。

3.2 .3 クリープ挙動の見地からした静クリープ破 断之の比較.

Fig. 9 はクリープ挙動の見地から静クリープ破断特 性と比較し，パルセイティング ストレスが溶接継手の 破断によ゙のような影響を及ぼすかをみるために，等佃静 応力 $\sigma_{e q}$ 一破断時間の関係を両対数值をとって示したも のである.

母材の特性とは異なり，短時間側では静クリープ破断 寿命よりも短いが長時間側では応力比Aのいかんにかか わらず静クリープ破断時間とほぼ等しくなっている。

このととは負荷応力の低い長時間破断のものでは，母 材と異なり，パルセイティングストレスによるクリープ 挙動以外のいわゆる “疲れ挙動”あるいは応力変動に伴 なう“過渡的なクリープ挙動”などの影響による破断寿 命の低下現象はあらわれないことを示しているもの之思 われる.

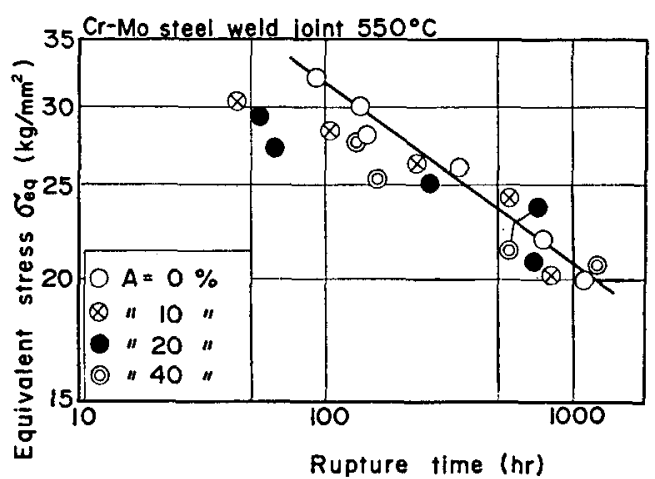

Fig. 9 Equivalent static stress versus time to rupture diagram

これに対し短時間側の50〜150時間附近では，母材の場 合とは異なり，静クリープ破断寿命よりもかなり顕著な 破断寿佮の低下が認められるのは，継手試験片の強度的 不均一性に上る治金的切久きによって繰り返し応力に敏 感となったためではないかと考えられる．すなわち継手 試験片の場合はFig.10亿示すような硬度分布を試験片の 中心に対して左右対称にあっているわけであるが，乙の 硬度差を形状的な断面変化之おきか元机ばそこにはいわ ゆる冶金的切炎きが存在するととになっで2, これがパ 


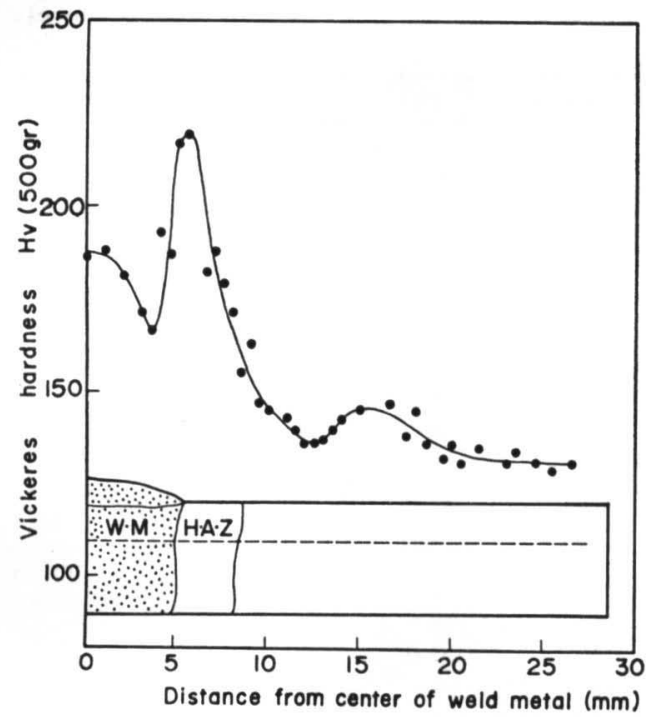

Fig. 10 Hardness distribution in welded joint

ルセイティング ストレスがもつ疲れ因子に対して感受 性を示し，そのために破断寿命の低下をきたしたのでは ないかと考えられる. この硬度不均一による治金的切欠 きはその温度における弾性域の応力状態に対しては効果 をもたないが, 降伏点をこえた塑性域で負荷応力が大き いほどその効果は大となる。応力の小さい長時間破断の ものにパルセィティング ストレスによる顕著な破断寿

$A=0 \%$

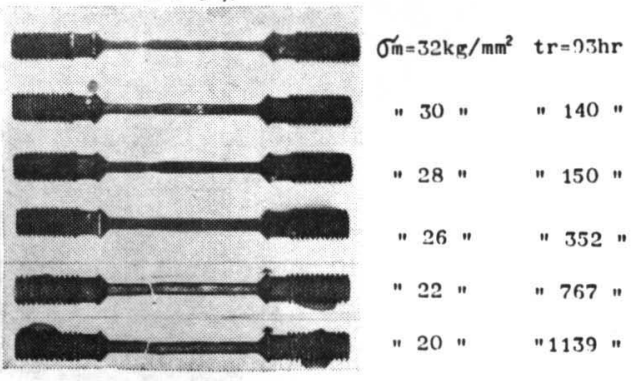

(a)

$A=10 \%$

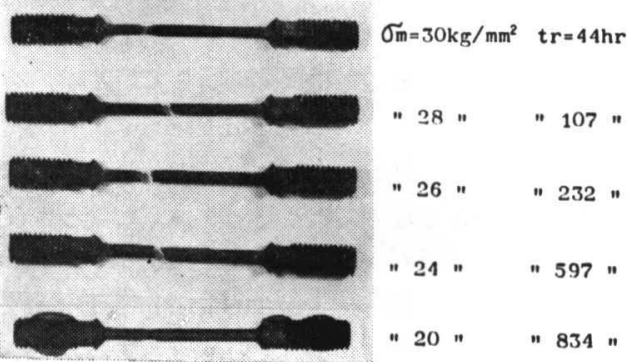

命の低下がみられないのは，乙のような冶金的切欠き効 果がほとんどあらわれないためであろうと考えられる.

Photo. 1 の破断後の試験片の外観写真でもわかるよ うに, 短時間破断のむのは溶接部はほとんど変形せず, 溶接部の両側にクピレ現象が認められるのであって, 静, 動応力をとわず, いずれも破断時間の短いものでは 組織的に変形抵抗の小さいととろに変形が集中して形状 的にあ断面変化を示している.

\section{2 .4 静・動両クリープの破断にいたるまでの変 形量ならびに材料の延性.}

Fig. 11 は, 母材の場合と同様, 破断後の試験片につ いて破断部真歪と破断時間の関係を求めたものであり, Fig. 12 は静クリープだけについて母材と溶接継手のそ れを比較したあのである. まず静クリープについていえ ることは母材に比べて丕がかなり小さくなっていること であって，長時間側では軟鋼のそれよりあ小さくなって いる．静クリープにおける破断時間と破断部真歪の関係 は，破断時間が長くなるほど歪は小さくなっており，乙 の傾向は母材の場合もまったく同様であるが, Fig. 11に 示すように，パルセィティング ストレス下の破断点は いづれも母材の場合よりもさらにバラッキは大きく, 静 クリープ破断との比較あるいは破断部丕に及ぼすパルセ ィティング ストレスの影響をみることは困難である. しかしパルセィティング ストレス下の破断の場合も

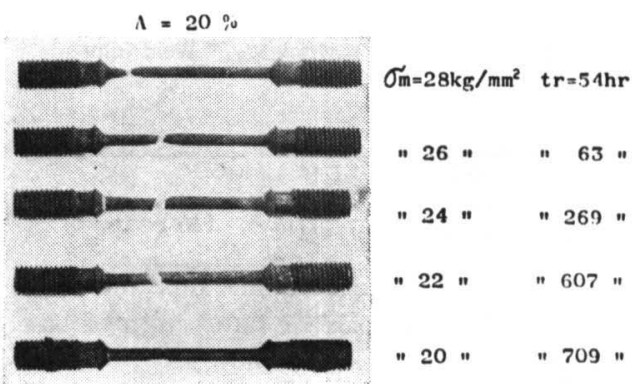

(c)

$A=40 \%$

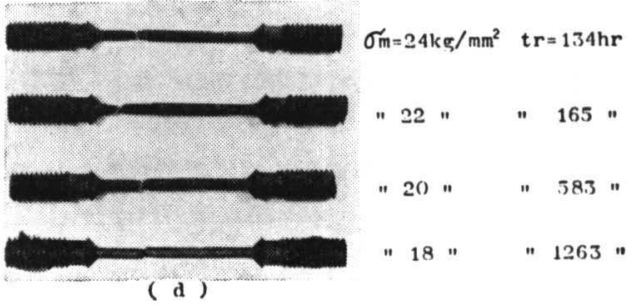

( b )

Photo. 1 Welded joint specimens after fracture at various stress in both static creep and pulsating stress rupture tests at $550^{\circ} \mathrm{C}$ 


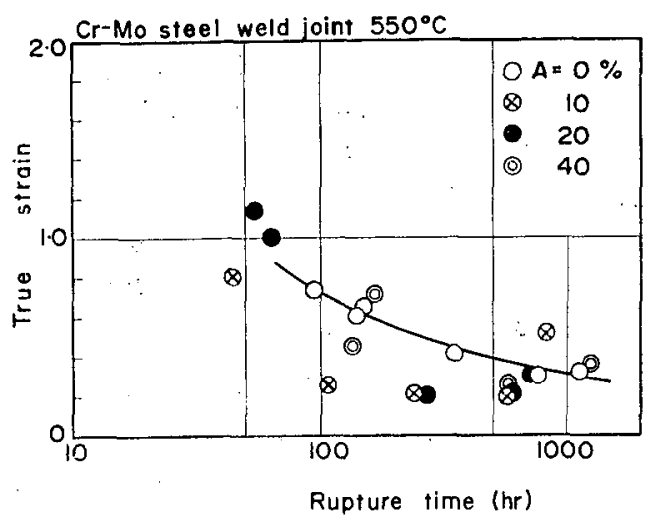

Fig. 11 Relation between ruptur time and strain at fractured part

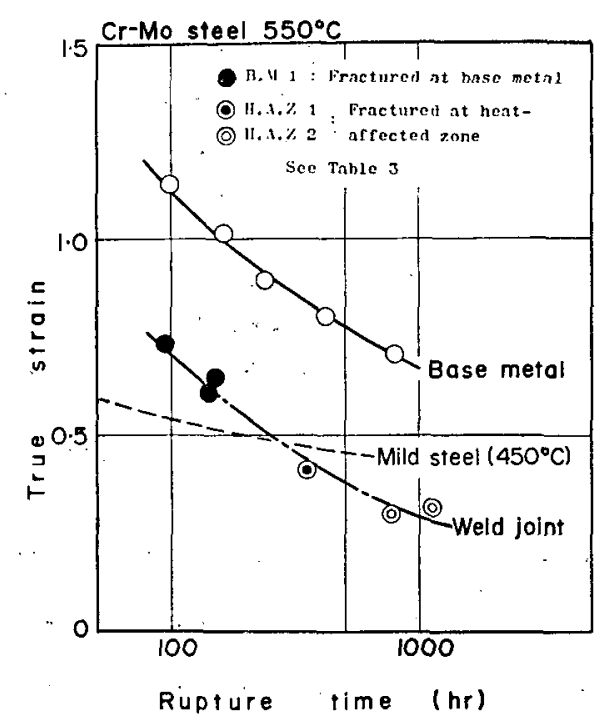

Fig. 12 Relation between rupture time and strain at fractured part for static creep of base metal and welded joint

辰㭙間破断の屯のほど歪は小さくなっており，暼クリー プ腋断と同様な傾问を示している。

\section{$3: 2.5$ 静, 動両クリープの破断位置について.}

以上は溶接継手の破断特性についてのべたあのである が，静クリープならびにパルセィティング ストレス下 の破断において，溶接継手のどてで破断がおこるかとい うことを比較検討することは，パルセイティング スト レスが溶接部に対してよ゙のよらな影響を及ぼすかを知 るうえに，また溶接継手の奏用上の見地からあまことに 重要である. Table 3 は，このような観点から，溶搷 継手試験片の静クリープ碳断ならびにパルセィティング
Table 3 Location of fracture in weld specimens

\begin{tabular}{|c|c|c|c|}
\hline $\begin{array}{l}\text { Mean stress } \\
\sigma_{m}\left(\mathbf{k g} / \mathrm{mm}^{2}\right)\end{array}$ & $\begin{array}{c}\text { Stress ratio } \\
\mathrm{A}(\%)\end{array}$ & $\begin{array}{l}\text { Rupture time } \\
\operatorname{tr}(\mathrm{hr})\end{array}$ & $\begin{array}{l}\text { Location of } \\
\text { fracture }\end{array}$ \\
\hline 32 & 0 & 93 & B.M (1) \\
\hline 30 & $"$ & 140 & $B \cdot M(1)$ \\
\hline 28 & " & 149 & B.M (1) \\
\hline 26 & $"$ & 352 & $\mathbf{H} \cdot \mathbf{A} \cdot \mathbf{Z}$ (1) \\
\hline 22 & $"$ & 767 & $\mathbf{H} \cdot \mathbf{A} \cdot \mathbf{Z}$ (2) \\
\hline 20 & $"$ & 1139 & H.A.Z (2) \\
\hline 30 & 10 & 44 & $\mathbf{B} \cdot \mathbf{M}(1)$ \\
\hline 28 & $"$ & 107 & B \\
\hline 26 & $"$ & 232 & $\mathbf{H} \cdot \mathbf{A} \cdot \mathbf{Z}$ (1) \\
\hline 24 & $"$ & 597 & B \\
\hline 20 & $"$ & 834 & H.A.Z (9) \\
\hline 28 & 20 & 54 & $\mathbf{B} \cdot \mathbf{M}$ (2) \\
\hline 26 & $"$ & 63 & $\mathrm{~B} \cdot \mathrm{M}$ (1) \\
\hline 24 & $" \prime$ & 269 & B \\
\hline 22 & $"$ & 607 & B \\
\hline 20 & $"$ & 709 & D (1) \\
\hline 24 & 40 & 134 & $B \cdot M \bigcirc$ \\
\hline 22 & $"$ & 165 & $\mathbf{B} \cdot \mathbf{M}$ (2) \\
\hline 20 & $"$ & 583 & $H \cdot a \cdot z$ (1) \\
\hline 18 & $"$ & 1263 & H.A.Z (2) \\
\hline
\end{tabular}

Note; B.M (1): Base metal neighbouring heat affected zone. B.M (2): Base metal distant from heat affected zone. H.A.Z(1): Heat affected zone near base metal-spheroidized pearlite structure, -

H, A.Z(2): Heat affected zone-fine grain structure-. $B$ : Bond.

D(1): Deposit metal neighbouring heat affected zone.

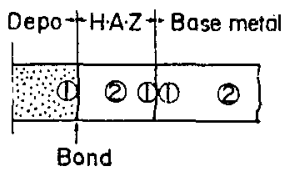

ストレス㢭断における砇断位置を示したずのであり， Photo. 2 はその忮断部の顕微鏡写真である。

まず静クリープの場合には，破断はいづれも目材熱影 響部に隣接した原質部あるいはそれに近い熱影響変質部 で起こっているが，応力の高いものから低いものへと㮌 次破断位置が溶接部に近ずく傾问を示している．すなわ ち応力の高い $32 \mathrm{~kg} / \mathrm{mm}^{2} 93$ 㭙間破断のあのは熱影響部

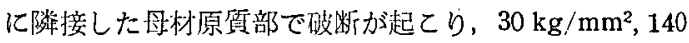

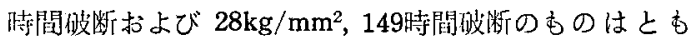
にそれよりもさらに熱影響部に近い，わずかにパーライ

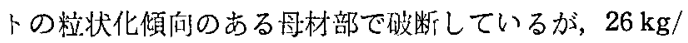
$\mathrm{mm}^{2}$, 352郝間貱断のあのになると明らかにパーライト の粒状化が認められる熱影響変質部で伐断している。応 力がもつと小さくなって破断恃間が長くなるとさらに溶 着金属部の力八近ずき, $22 \mathrm{~kg} / \mathrm{mm}^{2}, 767$ 壯間破断の屯 のでは蓺影響細粒部で，また $20 \mathrm{~kg} / \mathrm{mm}^{2}, 1139$ 時聞の あのはわずかではあるがそれよりもさらに溶着部答りと 思われる熱影響細粒部で破断している。乙れは Fig. 10 の便度分布に示すように，常温における溶控部の使度か 

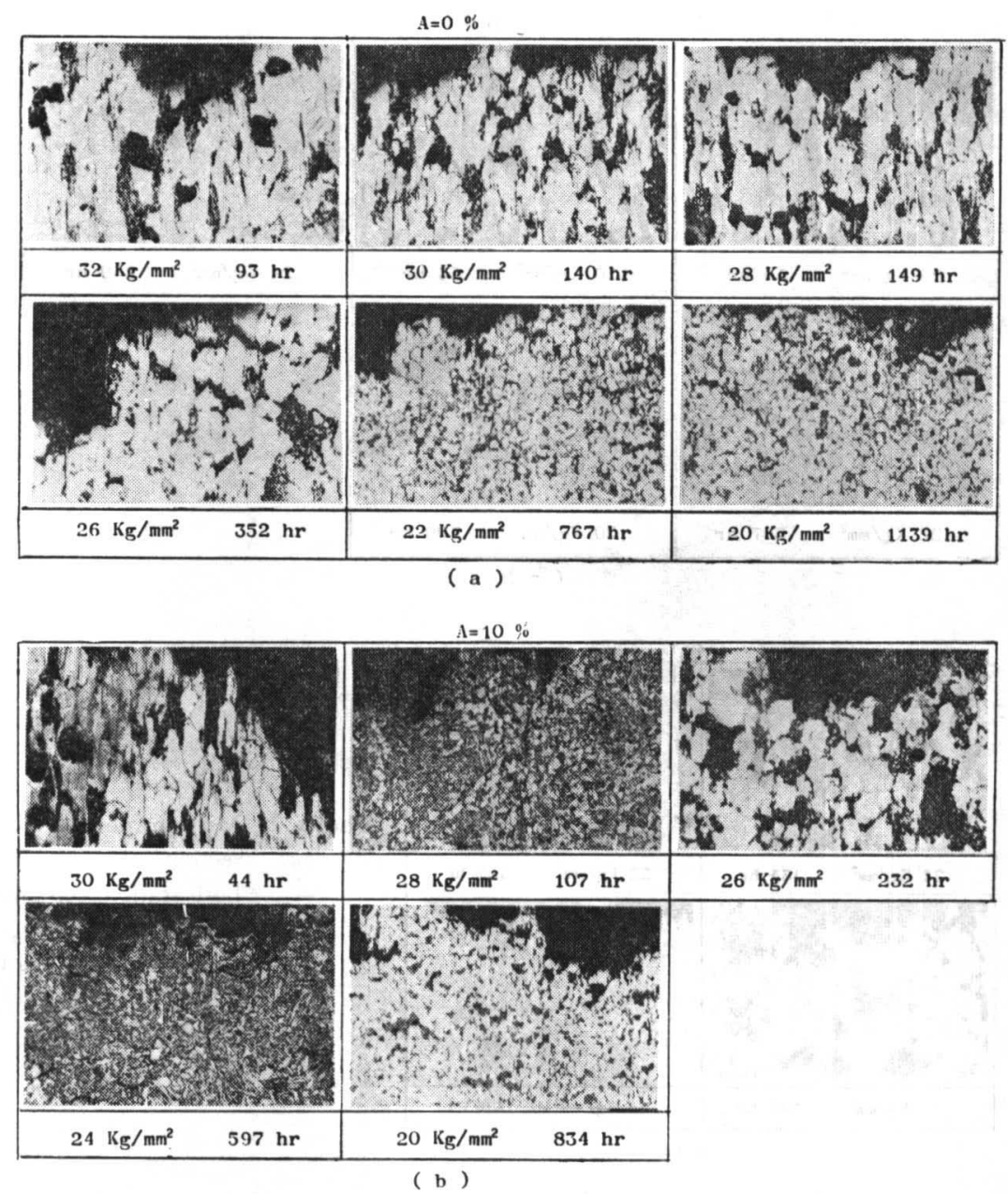

Photo. 2

ら推定した変形能とはあまり関係がないようで，かなら ずしも硬度の低いところで破断するとは限らず, 応力の 高い場合には母材と同程度の硬度の低いととろで破断し ているが, 応力が低くなるとむしろ硬度の高い熱影響細 粒部で破断している。これは長時間破断の場合は粒界破 断の傾向が強くなるために ${ }^{3)}$ 熱影響細粒部で破断しやす くなるものと考えられる.

パルセィティング ストレス下の破断の場合には，応 力比 $\mathrm{A} か ゙ 10 \%$ および $20 \%$ のあはとの破断位置が熱影響 部に近い原質部, 熱影響部で粒状パーライト化した部分 およびボンド近傍の 3 種類があり, 応力比 $\mathrm{A}$ が $40 \%$ のあ のは母材原質部, 熱影響部の粒. 状パーライト部および細 粒部之なっている. この場合も静クリープと同様応力が 高いものでは硬度の低い母材部で破断する傾向にあり，

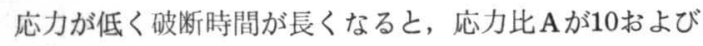
$20 \%$ ののでは熱影響部またはボンドで破断している
が, 応力比 Aが $40 \%$ では熱影響部で破断しており, ボン ドで破断したものは認められない。

いずれにしてもパルセィティング ストレス下の破断 の場合む, 静クリープ破断の場合と同様, 破断時間の長 いものほど破断位置が溶着部に近ずき, 結晶粒の細かい ところで破断する傾向があらわれている．したがって静 クリープ破断ではパルセィティング ストレス下の破断 のようにボンド部で破断した例はないが, 応力が高いと きには粒内すべりを主体とした塑性流動的なクリープ挙 動によっで3, 硬度の低い変形抵抗の小さい母材部で破 断し, 応力が低くなって破断時間が長くなると, 粒界破 壊の傾向が強くなって, むしろ硬度は高くても結晶粒の 細かい熱影響部へと破断位置が移動してくる傾向は両者 ともよく似ている.しかし溶接熱影響部あるいはボンド 部がとくにパルセィティング ストレスに対して敏感で あるという傾向は認められないようである. 

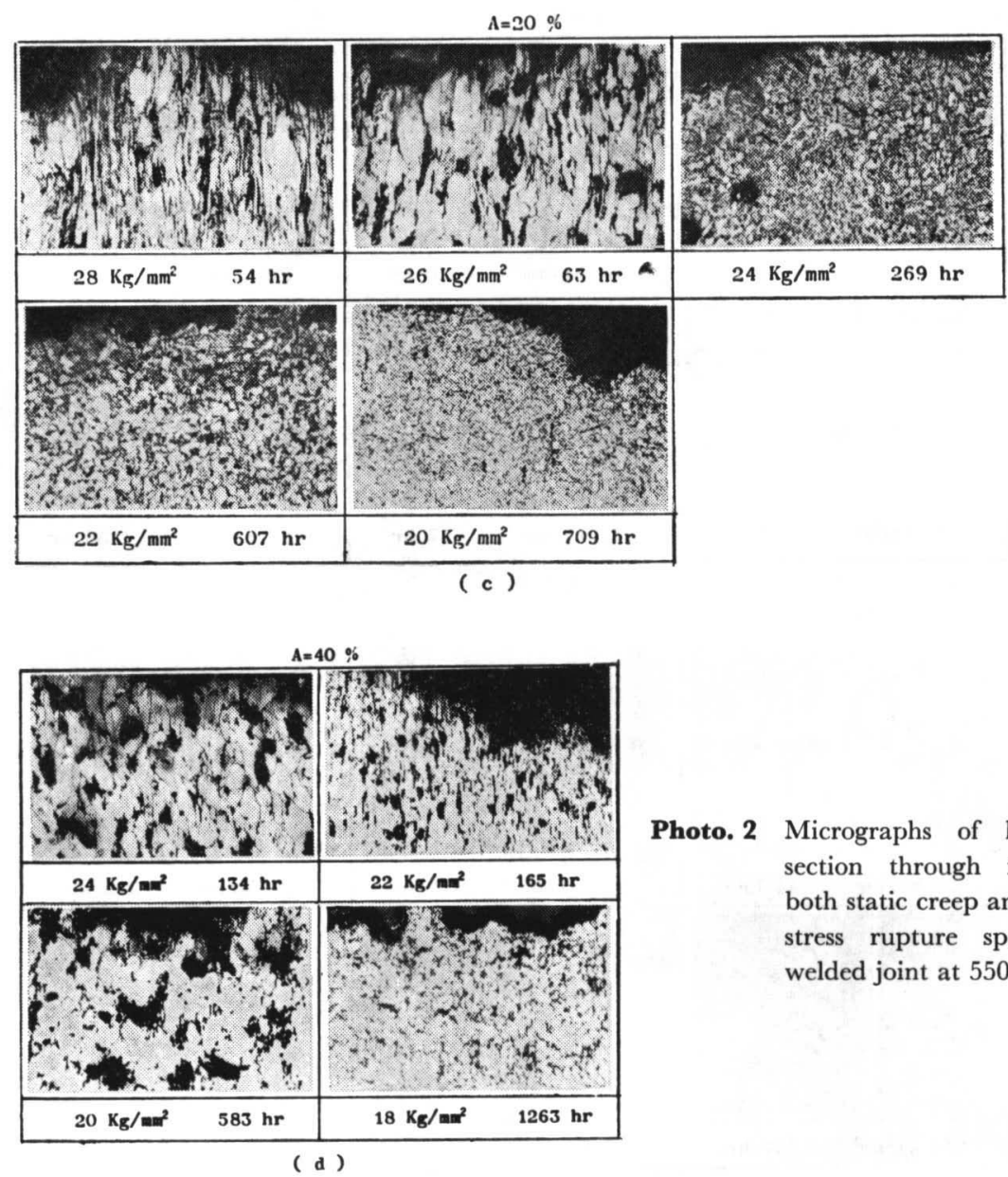

Photo. 2 Micrographs of longitudinal section through fracture of both static creep and pulsating stress rupture specimens of welded joint at $550^{\circ} \mathrm{C} ; \times 150$

\section{4. 結言}

$1 \mathrm{Cr}-1 / 2$ Mo 鋼およびその溶接継手について $550^{\circ} \mathrm{C}$ におけるパルセィティング ストレス クリープ破断試 験を行ない, 応力比 $\mathrm{A} か ゙ 40 \%$ までの比較的小さい場合の 破断特性を静クリープ破断特性と比較し, パルセィティ ング ストレスが母材ならびに溶接継手の破断に対して どのような影響を及ぼすかを検討したが, 本実験によっ てえられた結果を要約するとつぎのとおりである.

1） $550^{\circ} \mathrm{C}$ における $\mathrm{Cr}-\mathrm{Mo}$ 鋼のパルセィティング ストレス下の破断強度と破断時間の関係を繰り返し応力 の平均応力 $\sigma_{m}$ に対して求めてみると, 平均応力 $\sigma_{m}$ 一 定で静クリープさせたときの破断寿命がもっとも大き く, 同じ平均応力に対して応力振巾が大きいむのほど破 断寿命が著しく低下する. この現象は前報の $450^{\circ} \mathrm{C}$ に おける軟鋼の場合とまったく同様である.

2）パルセィティング ストレス下の破断特性をクリ ープ挙動の見地から静クリープ破断特性と比較してみる
と, 前報でのべた $450^{\circ} \mathrm{C}$ の軟鋼の場合とは異なり, 静 的クリープ損傷の累積によって破断すると考えたときの 破断寿命よりあ明らかに低下する現象が認められ，また その低下度は破断時間が長くなるほど大きくなるようで ある．この破断寿命の低下は，パルセィティング スト レスによる静的クリープ損傷のほかに, 疲れ損傷などが 重畳されたためであると考えられる。

3）破断後の試験片の破断部真歪が破断時間の長いむ のほど低下する傾向は, 静クリープ破断, パルセィティ ング ストレス破断とも同様であるが, 歪量はいずれも 軟鋼に比べてかなり大きくなっている．またパルセィテ ィング ストレス下の破断の場合には, バラッキがかな り大きいためにその特性を明確にすることは難しいが, 破断部真歪と破断時間の関係からは，パルセィティング

ストレス下の破断特性と静クリープ破断特性の差は, 等価静応力 $\sigma_{e q}$ による静クリープ破断強度との差のよう に明確にはあらわれない. 
4）溶接継手のパルセィティング ストレス下の破断 をクリープ挙動の見地から静クリープ破断特性と比較し てみると，母材の場合とは異なり，短時間破断のむのは 破断寿命の低下は認められるが，長時間破断のものは静 クリー-プのそれにほぼ等しくなる。

5）乙の長時間側で静クリープ破断寿命との差がほと んごみられないのは，溶接継手の静クリープ破断におけ る破断部真歪が母材に比べて著しく小さく，軟鍋のそれ に近くなるこよからみて， $450^{\circ} \mathrm{C}$ の軟鋼の破断特性 と 同様な特性を示したすのと考えられる。

6）溶接継手の破断位置は静クリープ破断およびパル セィティング ストレス破断とも顕著な相違は認めら れず，短時間破断のものは熱影響部に隣接した常温硬度 のもっとも低い原質部で破断するようであるが，破断時 間が長くなるほどいずれも硬度の高い熱影響細粒部へ之 破断位置が移行する傾向がある。したがって長時間破断 のものの破断強度は継手の硬度分有之あまり関係がない ようである．乙れはその破壊形式が粒界破壊の傾向が強 くなるためであるうと考えられる。

7）本実験の結果からすれば，溶接熱影響部あるいは 溶着金属部がとくにパルセィティング ストレスの影響 をうけ，静クリープに比へて破断寿命が著しく低下する というような現像は認められない。
8） $550^{\circ} \mathrm{C}$ の $\mathrm{Cr}-\mathrm{Mo}$ 鋼は $450^{\circ} \mathrm{C}$ の軟鋼に比べてパ ルセィティング ストレスに対する感受性が高い上うで あり，長時間破断のものほどその傾向は大きい，乙れに 対し継手の場合は，短時間破断のむのに破断寿命の低下 が認められるが，長時間破断のものには認められず，軟 鋼と同様，パルセィティング ストレスに対してはあま り敏感ではないと考えられる。

謝辞

本研究に際して種々便宜を計って頂くととも実験結 果に対する討議の場を設けて頂いた関西電力株式会社, 材料の提供を頂いた住友金属株式会社ならびに溶接継手 の製作その他実験に便宜を計って頂いた汽車製造株式会 社に対して澡く謝意を表するしだいである。

また本研究を行なうに当たり当時学生の岡本善一郎, 松本保治両君の熱心な御協力を得た。こてに併せて謝意 を表する。

\section{参考文 献}

1）渡迅，小川，“パルセイティングスレスクリーブ特性に関する研究 (1)”溶接学会袐 Vol，35, No. 12, 1966

2）峰久，“軟銅溶接継手の疲れに関する研然”学位請求論文（昭和37 年)

3) 例之は G.V. Smith "Properties of Metals at Elevated Temperatures" N.Y. MCGRAW-HILL BOOK CO, INC. (1950)

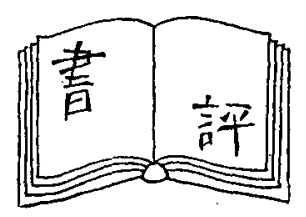

\section{「溶 接 の自 動 化」}

工学博士 寺井 清著 (産報)

寺井清博士がこれまでの論文にさらに一交を加え，「溶接の自動化」という単行本をまとめられた。 と れはただ，あれとれの自動溶接法の解説書ではない，「哲学的方法諭の技術革新への適用」とでむ呼ぶべ き内容のものである.

ただし，だからといって難解な暂学書ではない，具体的な写真を豊富に収録した溶接技術に関係した本 である.

溶接技術の発達が10年前の状沉から，今日を推論したのと同じような延長線上に10年後が想像されれば， このような本は書かれなかったであろう，われわれの社会が神の摂理のままに動くと考えられた時代に， 科学的な哲学が必要でなかったと同じように.

しかし, 社会の急激な变革の時, 明日の日を予測し, 明日の日に備元得るのは, 変革の中にある客観的 な法則性を理解し，それに対処する正しい力法を見出した人だけである.

技術の世界にあ同様なことがあることを，溶接の自動化を例に具体的に示したのが，この本である。 そ してての本の説得力は, 寺开博士がその力法論にもとずいて, 今日のもっとも合理的溶接技術の管理を造 船所で確立し，それを基礎にすでに明日の造船所を創り出す努力を，日夜第一線で続けられているてとに ある。

同博士は，この業績に対し，昨年大河内記念賞を受賞され，また本年第 1 回の溶接学会田中亀久人賞を 受けられている。

この本は，溶接自動化のためのハンド・ブックではない，しかし技術者が自分で考えて何かを生み出す ためには，かならず参考になる本である。（益本 功） 